\title{
PENGARUH PROBIOTIK Saccharomyces spp. DALAM RANSUM TERHADAP KECERNAAN PAKAN DAN KANDUNGAN GAS AMMONIA DALAM EKSKRETA AYAM
}

\author{
BIDURA, I G. N. G. \\ Fakultas Peternakan, Universitas Udayana, Denpasar-Bali, Indonesia \\ e-mail: gde_bidura@unud.ac.id
}

\begin{abstract}
ABSTRAK
Penelitian ini bertujuan untuk mengkaji pengaruh pemberian probiotik Saccharomyces spp.N-2 (isolat dari ragi tape) dalam ransum ayam petelur untuk meningkatkan kecernaan dan menurunkan jumlah amonia dalam ekskreta. Sebanyak seratus dua puluh ayam petelur dewasa umur 40 minggu digunakan dalam percobaan rancangan acak lengkap (RAL) dengan empat dan enam kali ulangan. Keempat macam perlakuan, yaitu: ransum tanpa pemberian probiotik sebagai kontrol (A); ransum dengan penambahan 0,10\% Saccharomyces spp. $N$-2 (B); ransum dengan $0,20 \%$ Saccharomyces spp.N-2 (C); dan ransum dengan o,30\% Saccharomyces spp.N-2 (D). Hasil penelitian menunjukkan bahwa kecernaan bahan kering, bahan organik, dan protein kasar ransum meningkat nyata $(\mathrm{P}<0,05)$ pada ayam perlakuan $\mathrm{B}, \mathrm{C}$, dan $\mathrm{D}$. Sedangkan diantara perlakuan $\mathrm{B}, \mathrm{C}$, dan $\mathrm{D}$, berbeda tidak nyata ( $\mathrm{P}>0,05)$. Jumlah bakteri Choliform, E. coli dalam saluran pencernaan ayam Grup B, C, dan D, secara signifikan $(\mathrm{P}<0,05)$ menurun dibandingkan dengan kontrol (Grup A). Demikiann juga halnya dengan kadar gas amonia $\left(\mathrm{N}-\mathrm{NH}_{3}\right)$ dalam ekskreta ayam, menurun secara nyata $(\mathrm{P}<0,05)$ dengan adanya suplementasi probiotik dalam ransum. Disimpulkan bahwa penambahan 0,10-0,30\% probiotik Saccharomyces spp.N-2 dalam ransum dapat meningkatkan kecernaan ransum, serta menurunkan kandungan bakteri E. coli dan gas amonia dalam ekskreta ayam petelur Lohmann Brown.
\end{abstract}

Kata kunci : Eschericia coli, protein, probiotik, ayam petelur

\section{THE EFFECT OF SACCHAROMYCES SPP PROBIOTICS IN FEED LAYING HENS TO INCREASE FEED DIGESTIBILITY AND REDUCE AMMONIA GAS CONTENT IN EXCRETA}

\begin{abstract}
This study aims to examine the effect of adding probiotic Saccharomyces spp.N-2 (isolates from yeast tape) into the rations of laying hens to increase feed digestibility and reduce the amount of ammonia gas in excreta. One hundred twenty laying hens aged 40 weeks were used in a complete randomized design (CRD) study with four treatments and six replications. The four types of treatment, namely: ration without the provision of probiotics as a control (A); ration with the addition of 0.10\% Saccharomyces spp.N-2 (B); ration with $0.20 \%$ Saccharomyces spp.N-2 (C); and rations with 0.30\% Saccharomyces spp.N-2 (D). The results showed that the digestibility of dry matter, organic matter, and crude protein increased significantly $(\mathrm{P}<0.05)$ in chickens of group $\mathrm{B}, \mathrm{C}$ and $\mathrm{D}$. Among the treatments of group B, C, and D, there was no significant difference ( $\mathrm{P}>0.05)$. The number of Choliform bacteria, E. coli in the digestive tracts of chicken in Group B, C, and D, significantly $(\mathrm{P}<0.05)$ decreased compared

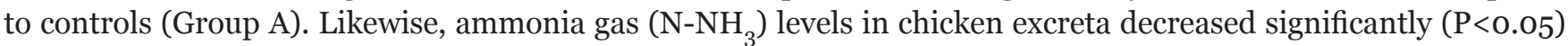
with the presence of probiotic supplementation in the ration. It was concluded that the addition of 0.10-0.30\% Saccharomyces spp.N-2 probiotics in the ration could increase the digestibility of the ration, as well as reduce the content of $E$. coli bacteria and ammonia gas in the excreta in Lohmann Brown laying hens.
\end{abstract}

Keywords : Eschericia coli, protein, probiotics, laying hens 


\section{PENDAHULUAN}

Umumnya, sekitar 80\% dari hewan domestik yang dipelihara secara komersial pakannya mengandung senyawa sintetis untuk tujuan pengobatan atau memacu pertumbuhan. Pelarangan penggunaan antibiotik sebagai pakan aditif di Indonesia sejak 1 Januari 2018, telah memicu para peneliti untuk menemukan aditif pakan tradisional sebagai pengganti penggunaan antibiotik dalam pakan ternak. Penggunaan antibiotik yang berlebihan atau dalam dosis rendah, tetapi diberikan secara terus menerus dapat meninggalkan residu pada produk ternak (Bidura dan Gomes, 2019). Telur adalah produk ternak yang berpotensi mengandung residu antibiotik ketika antibiotik digunakan secara berlebihan atau terus menerus (Bidura et al., 2010). Upaya mengurangi penggunaan antibiotik, salah satunya adalah menggunakan probiotik (Tang et al., 2018).

Ternak unggas yang mempunyai produksi yang tinggi (telur dan daging), daya adaptasi terhadap lingkungan yang tinggi, namun mempunyai kelemahan, yaitu memproduksi kadar gas amonia yang cukup tinggi (Bidura et al., 2010). Untuk menekan kadar amonia dan bakteri patogen perlu dicari suatu bahan pakan alternatif dengan probiotik.

Probiotik adalah mikroba hidup yang diberikan sebagai suplemen makanan dengan tujuan memperbaiki kesehatan dan perkembangan mikroba (Bidura, 2007). Menurut Barrow (1992), probiotik adalah imbuhan pakan berbentuk mikroba hidup yang menguntungkan dan mempengaruhi induk semang melalui perbaikan keseimbangan mikroorganisme dalam saluran pencernaan ternak, memberikan keuntungan pada inang melalui seleksi yang selektif pada pertumbuhan dan aktivitas dari satu atau sejumlah bakteri yang terdapat di dalam kolon ternak unggas.

Khamir Saccharomyces spp telah lama digunakan sebagai inokulan fermentasi dalam pembuatan "tape", dan penggunaannya di dalam ransum ternak unggas dapat bertindak sebagai probiotik untuk meningkatkan kinerja ternak unggas (Bidura et al., 2012; 2015; 2016; 2019; Hasan et al., 2016; Siti et al., 2014; Ezema dan Eze, 2015; Carvalho et al., 2019; Partama dan Bidura, 2019), dapat meningkatkan ekologi bakteri saluran pencernaan dan respon imun pada anak ayam, sehingga, menjadi model baru untuk strategi masa depan dalam pengendalian penyakit pada ternak unggas (Hasan et al., 2016; Hasanuddin et al., 2017; Zhen et al., 2019).

Penggunaan probiotik pada ternak unggas dilaporkan dapat menurunkan aktivitas enzim urease, suatu enzim yang bekerja menghidrolisis urea menjadi ammonia, sehingga pembentukan amonia menjadi berkurang atau bahkan hilang. Amonia adalah suatu bahan yang dapat menyebabkan keracunan pada ternak unggas (Yeo dan Kim, 1997). Penelitian Asli et al. (2007) tentang probiotik yeast S.cerevisiae yang dikombinasikan dengan vitamin $\mathrm{E}$ dan $\mathrm{C}$ membuktikan bahwa probiotik tersebut mampu meningkatkan daya tahan tubuh unggas. Suplementasi o,20-0,30\% probiotik Saccharomyces spp. (isolat rumen kerbau) dalam ransum dapat meningkatkan efisiensi pakan serta penurunan kadar kolesterol dalam kuning telur ayam petelur (Bidura, 2019).

Berdasarkan hal tersebut peneliti ingin mengkaji lebih mendalam mengenai pengaruh level pemberian probiotik khamir Saccharomyces $s p p N-2$ dalam ransum ayam petelur Lohmann Brown dilihat dari aspek kecernaan pakan, serta jumlah E.coli, Choliform, dan kadar amonia dalam ekskreta ayam.

\section{MATERI DAN METODE}

\section{Ternak Ayam dan Rancangan Percobaan}

Ayam yang digunakan adalah ayam petelur dewasa yang sedang bertelur umur 40 minggu strain Lohmann Brown dengan berat badan homogen $(1678,31 \pm 28,54$ g). Ayam diperoleh dari peternak ayam petelur di sekitar tempat penelitian yaitu di Desa Penebel, Tabanan, Bali. Rancangan yang digunakan adalah rancangan acak lengkap (RAL) dengan empat macam perlakuan dan enam kali ulangan. Semua ransum perlakuan adalah isoenergi dan iso-protein. Ransum disusun sesuai dengan kebutuhan ayam petelur yang direkomendasikan oleh Scott et al. (1982) selama 10 minggu percobaan. Bahan pakan dan komposisi kimia dari pakan disajikan pada Tabel 1.

Kandang yang digunakan adalah kandang "battery colony" yang terbuat dari kawat dan bilah bambu. Ukuran tiap petak kandang adalah: panjang $40 \mathrm{~cm}$, lebar $40 \mathrm{~cm}$, dan tinggi $40 \mathrm{~cm}$, untuk dua ekor ayam petelur. Kandang disusunan bertingkat memanjang di dalam sebuah bangunan kandang dengan atap dari asbes. Jumlah kandang seluruhnya adalah sebanyak 120 petak kandang @ 2 ekor. Penerangan pada malam hari menggunakan bola lampu listrik. Tempat ransum terbuat dari pipa paralon, demikian juga halnya dengan tempat air minum volume 2 liter yang ditempatkan pada masing-masing petak kandang.

\section{Probiotik Saccharomyces spp.}

Kultur probiotik yang digunakan adalah khamir Saccharomyces spp.N-2 yang potensial sebagai probiotik, mempunyai aktifitas CMC-ase yang diisolasi dari ragi tape (Bidura et al., 2012). Probiotik selanjutnya dicampurkan ke dalam ransum dan diberikan kepada ayam petelur secara feeding trial dilihat dari aspek kecernaan, jumlah bakteri Choliform dan E. coli, serta kadar amonia dalam ekskreta ayam. 
Table 1. Komposisi bahan pakan dan zat makanan dalam ransum ayam petelur Lohmann Brown umur 40-50 minggu

\begin{tabular}{|c|c|c|c|c|c|}
\hline \multirow{2}{*}{ Komposisi (\%) } & \multicolumn{5}{|c|}{ Probiotik Saccharomyces spp.N-2 } \\
\hline & & $0 \%$ & $0,10 \%$ & $0,20 \%$ & $0,30 \%$ \\
\hline Jagung kuning & & 55,30 & 55,30 & 55,30 & 55,30 \\
\hline Dedak padi & & 17,00 & 16,90 & 16,80 & 16,70 \\
\hline Kacang kedelai & & 4,00 & 4,00 & 4,00 & 4,00 \\
\hline Tepung ikan & & 13,20 & 13,20 & 13,20 & 13,20 \\
\hline Mineral-B12*) & & 5,00 & 5,00 & 5,00 & 5,00 \\
\hline Saccharomyces spp. $\mathrm{N}-2$ & & 0,0 & 0,10 & 0,20 & 0.30 \\
\hline Total & & 100 & 100 & 100 & 100 \\
\hline \multicolumn{6}{|c|}{ Komposisi zat makanan $* *)$ : } \\
\hline Energi termetabolis & (kcal/kg) & 2750,15 & 2748,51 & 2747,0 & 2745,99 \\
\hline Protein kasar & (\%) & 17,02 & 17,00 & 17,00 & 16,99 \\
\hline Serat kasar & (\%) & 4,23 & 4,22 & 4,21 & 4,19 \\
\hline Lemak kasar & (\%) & 6,36 & 6,36 & 6,36 & 6,33 \\
\hline Calsium & (\%) & 3,76 & 3,76 & 3,76 & 3,76 \\
\hline P-available & (\%) & 1,40 & 1,40 & 1,40 & 1,40 \\
\hline Lysin & (\%) & 1,23 & 1,23 & 1,23 & 1,23 \\
\hline Metionin+sistein & (\%) & 0,75 & 0,75 & 0,75 & 0,75 \\
\hline Triptofan & (\%) & 0,18 & 0,18 & 0,18 & 0,18 \\
\hline
\end{tabular}

*) Komposisi Mineral-B12 per $10 \mathrm{~kg}$ : Calsium: 49\%; Phosphor 14\%; Iron: $40000 \mathrm{mg}$. Manganese: 27500 mg; Mg: 27.500 mg; Zinccum: 25 mg; Vit-B12: 4.50 mg and Vit D3: 500000 IU. PT. Eka Farma. Deptan RI No. D 8109127 FTS

**) Berdasarkan perhitungan Scott et al. (1982)

\section{Prosedur Penelitian dan Variabel yang Diamati}

Kecernaan bahan pakan: Untuk menentukan nilai kecernaan nutrisi (bahan kering, kecernaan bahan organik, dan protein kasar), dilakukan dengan metode metode koleksi total selama tiga hari. Terlebih dahulu, ayam ditempatkan pada kandang individu yang sudah dilengkapi dengan tempat pakan dan air minum, serta dibawah alas kandang ditempatkan napan untuk menampung ekskreta. Kandang individu berukuran: panjang $40 \mathrm{~cm} \times$ lebar $20 \mathrm{~cm} \times$ tinggi $40 \mathrm{~cm}$. Setelah ayam dimasukkan ke dalam kandang individu, hari pertama ayam hanya diberikan air minum saja, dan dipuasakan dari pakan agar supaya saluran pencernaan ayam menjadi kosong. Hari kedua sampai keempat (tiga hari), ayam diberikan pakan sebanyak $110 \mathrm{~g} /$ ekor/ hari (jumlah ini berdasarkan penelitian sebelumnya bahwa rataan banyaknya ransum yang dikonsumsi oleh ayam adalah $110 \mathrm{~g} /$ ekor/hari) dan di bawah lantai kandang sudah disiapkan penampung ekskreta dari nampan plastik. Koleksi total dilakukan selama tiga hari berturut turut. Pada hari ketiga dari koleksi total, pemberian pakan dihentikan, akan tetapi pemberian air minum tetap disediakan. Pada hari ke empat dari koleksi total, ekskreta dikumpulkan dan dibersihkan dari segala kotoran (bulu dan sisa pakan). Total kotoran (kotoran) dikumpulkan dalam baki plastik. Sampel kotoran kemudian dioven pada temperatur $105^{\circ} \mathrm{C}$ sampai didapat berat konstan, kemudian ditimbang dan ditumbuk, serta disaring $1 \mathrm{~mm}$. Sampel ekskreta dan pakan kemudian dianalisis untuk menentukan kandungan bahan kering (DM) dan bahan organik (OM), masing-masing. Bahan kering (DM) dan bahan organik (OM), dan penentuan abu dilakukan sesuai dengan AOAC (2005). Semua tes dilakukan dalam rangkap tiga. Untuk menentukan kecernaan bahan kering (KCBK), kecernaan bahan organik (KCBO); dan kecernaan protein kasar (KCPK) ransum adalah berdasarkan bahan kering (DM) dengan formula:

$\operatorname{KCBK}(\%)=$

(konsumsi bahan kering ransum - Jumlah bahan kering ekskreta) x 100\% Konsumsi bahan kering ransum

$\mathrm{KCBO}(\%)=$

(konsumsi bahan organik ransum - Jumlah bahan organik ekskreta) x 100\% Konsumsi bahan organik ransum

$\mathrm{KCPK}(\%)=$

(konsumsi protein kasar ransum - Jumlah protein kasar ekskreta) x 100\% Konsumsi protein kasar ransum

Total plate count (TPC): TPC merupakan teknik menghitung jumlah seluruh mikroba yang terdapat pada ekskreta dengan menggunakan media PCA (Plate Count Agar) untuk analisis total plate count ekskreta dengan metode tuang (Fardiaz, 1992). Penanaman ini dilakukan di dalam ruang steril dan berdekatan dengan api bunsen, hal ini bertujuan untuk menghindarkan kontaminasi dari lingkungan luar, dengan jalan mengambil tingkat pengenceran $10^{-5}, 10^{-6}$, dan $10^{-7}$ dengan pipet masing-masing dituangi dengan media PCA (suhu $\pm 45^{\circ} \mathrm{C}$ ) ke dalam cawan petri sebanyak 20 ml dan ditutup kembali. Selanjutnya dihomogenkan dengan menggerakkan cawan petri dengan hati-hati dan biarkan hingga media memadat. Penanaman dibuat rangkap dua (duplo) ke dalam inkubator dengan suhu $37^{\circ} \mathrm{C}$ dalam kondisi terbalik, dan hasil dapat dihitung 24-48 jam.

Pengujian bakteri Coliform dan Escherichia coli: Adapun metode yang digunakan untuk memperoleh total bakteri Escherichia coli dan Coliform yaitu metode sebar (Fardiaz, 1992) menggunakan media EMBA, yaitu sebanyak 5 gr ekskreta dimasukkan ke dalam tabung Erlenmeyer yang telah berisi larutan pepton water $0,1 \%$ dengan volume $45 \mathrm{ml}$, sehingga didapatkan pengenceran $10^{-1}$. Untuk menghitung koloni bakteri yang tumbuh menggunakan metode hitungan cawan, yakni dengan memilih jumlah koloni yang tumbuh pada cawan petri berkisar antara 30-300 koloni (Fardiaz, 1992). Rumus: koloni/gram = jumlah koloni per cawan $\times 1 /$ faktor pengencer.

Kadar $\mathrm{N}-\mathrm{NH}_{3}$ ekskreta: penentuan kadar $\mathrm{N}-\mathrm{NH}_{3}$ dengan menggunakan difusi Conway (Saransi et al., 2010) sebagai berikut: $1 \mathrm{ml}$ sampel supernatant disebelah kiri sekatan cawan Conway, $1 \mathrm{ml}$ larutan $\mathrm{Na}_{2} \mathrm{CO}_{3}$ jenuh pada sekat sebelah kanan, $1 \mathrm{ml} \mathrm{H}_{3} \mathrm{BO}_{3}$ $2 \%$ yang berindikator BCG + MR pada cawan tengah, 
kemudian tutup cawan conway bervaselin dengan rapat, goyang dengan perlahan sampai supernatant dengan $\mathrm{Na}_{2} \mathrm{CO}_{3}$ bercampur sempurna, kemudian biarkan 24 jam dalam suhu kamar, selanjutnya lakukan titrasi dengan menggunakan $\mathrm{H}_{2} \mathrm{SO}_{4}$ O, $005 \mathrm{~N}$ sampai titik akhir titrasi. Kadar $\mathrm{N}-\mathrm{NH}_{3}$ dapat dihitung sebagai berikut ini: $\mathrm{mM} \mathrm{N}-\mathrm{NH}_{3}=\left(\right.$ Volume titrasi $\times \mathrm{N} \mathrm{H}_{2} \mathrm{SO}_{4} \times 1$.000 $)$.

\section{Analisis Statistika}

Analisis yang digunakan untuk semua data yang diperoleh adalah analisis sidik ragam satu arah (oneway ANOVA) dan apabila terdapat perbedaan yang nyata $(\mathrm{P}<0,05)$ di antara perlakuan, maka dilanjutkan dengan uji jarak berganda dari Duncan (Steel and Torrie, 1989).

\section{HASIL DAN PEMBAHASAN}

\section{Kecernaan Zat Makanan}

Hasil penelitian menunjukkan, kecernaan bahan kering (KCBK) ransum pada ayam yang diberi ransum tanpa probiotik (Grup A) adalah 72,19\% (Tabel 2). Suplementasi probiotik Saccharomyces spp.N-2 dalam ransum ayam Grup B, C, dan D, berbeda nyata $(\mathrm{P}<0,05)$ lebih tinggi, yaitu: 3,82\%; 3,73\%; dan 4,21 daripada kontrol (A). Sedangkan diantara perlakuan Grup B, C, dan $\mathrm{D}$, menunjukkan berbeda tidak nyata $(\mathrm{P}>0,05)$.

Penambahan probiotik Saccharomyces spp.N-2 dalam ransum secara nyata $(\mathrm{P}<0,05)$ dapat meningkatkan kecernaan bahan organik (KCBO) ransum pada ayam Grup B, C, dan D, meningkat masing-masing: 3,01\%; 3,48\%; dan 3,73\% lebih tinggi daripada kontrol (Tabel 2). Demikian juga halnya dengan kecernaan protein kasar (KCPK) meningkat secara signifikan $(\mathrm{P}<0,05)$ dengan adanya penambahan probiotik dalam ransum ayam Grup B, C, dan D, masingmasing: 3,66\%; 4,16\%; dan 4,45\% lebih tinggi daripada kontrol (tanpa probiotik).

Seperti tersaji pada Tabel 2, KCBK dan KCBO pada ayam Grup B, C, dan D lebih tinggi dari kontrol. Peningkatan ini disebabkan karena probiotik di dalam saluran pencernaan ayam dapat meningkatkan aktifitas enzimatis dan penyerapan zat-zat makanan (Barrow, 1992; Zurmiati et al., 2014; Bidura et al., 2012). Hasil ini terbukti pada penelitian (Bidura dan Siti, 2017; Bidura et al., 2012; 2014; 2017) yang melaporkan bahwa penggunaan probiotik dalam ransum dapat meningkatkan kecernaan bahan kering dan bahan organik ransum, serta meningkatkan kualitas nutrisi pakan.

Peningkatan kecernaan protein (KCPK) disebabkan protein yang masuk dari konsumsi protein dalam jumlah yang tinggi, sehingga protein yang mengikat kalsium dengan mekanisme Calcium Binding Protein (CaBP)
Tabel 2. Tingkat penambahan probiotik Saccharomyces spp. N-2 dalam ransum terhadap kecernaan nutrien, jumlah Choliform, Eschericia coli dan $\mathrm{N}-\mathrm{NH}_{3}$ dalam ekskreta ayam

\begin{tabular}{lccccc}
\hline \multirow{2}{*}{ Variabel } & \multicolumn{5}{c}{ Groups $^{1)}$} \\
\cline { 2 - 6 } & $\mathrm{A}$ & $\mathrm{B}$ & $\mathrm{C}$ & $\mathrm{D}$ & \\
\hline Kecernaan bahan kering (\%) & $72,19 \mathrm{~b}^{3)}$ & $74,95 \mathrm{a}$ & $74,88 \mathrm{a}$ & $75,23 \mathrm{a}$ & 0,502 \\
Kecernaan bahan organik (\%) & $73,81 \mathrm{~b}$ & $76,03 \mathrm{a}$ & $76,38 \mathrm{a}$ & $76,56 \mathrm{a}$ & 0.617 \\
Kecernaan protein kasar (\%) & $76.25 \mathrm{~b}$ & $79,04 \mathrm{a}$ & $79,42 \mathrm{a}$ & $79,64 \mathrm{a}$ & 0,971 \\
Mikroba saluran pencernaan (Log CFU/g) & & & & \\
- Bakteri Choliform & $5,15 \mathrm{a}$ & $4,22 \mathrm{~b}$ & $4,27 \mathrm{~b}$ & $4,07 \mathrm{a}$ & 0,025 \\
- Bakteri Eschericia coli & $4,72 \mathrm{a}$ & $3,59 \mathrm{~b}$ & $3,31 \mathrm{~b}$ & $3,26 \mathrm{~b}$ & 0,071 \\
- Total bakteri/TPC & $9,05 \mathrm{a}$ & $8,72 \mathrm{a}$ & $7,99 \mathrm{a}$ & $7,81 \mathrm{a}$ & 0,419 \\
$\mathrm{~N}-\mathrm{NH}_{3}$ (m.Mol) & $37,26 \mathrm{a}$ & 32,79 & $32,65 \mathrm{~b}$ & $31,53 \mathrm{a}$ & 1,094 \\
\hline
\end{tabular}

Keterangan:

Ransum tanpa pemberian probiotik sebagai kontrol (A); ransum dengan penambahan $0,10 \%$ Saccharomyces spp. $N-2$ (B); ransum dengan $0,20 \%$ Saccharomyces spp. $N-2$ (C), dan ransum dengan $0,30 \%$ Saccharomyces spp. $\mathrm{N}-2$ (D).

SEM: Standard Error of Treatment Means

Nilai dengan huruf yang sama pada baris yang sama menunjukkan berbeda nyata $(\mathrm{P}<0,05)$

akan tinggi dan absorbsi kalsium untuk dideposisi dalam tubuh (telur) akan meningkat pula. Menurut Syafitri et al. (2015), massa kalsium daging dalam telur berhubungan dengan kecernaan protein, karena ketersediaan kalsium sangat berhubungan dengan asupan protein dengan membentuk ikatan Calcium Binding Protein (CaBP) yang akan membawa kalsium dalam sel mukosa usus dan diangkut oleh pembuluh darah menuju jaringan yang dibutuhkan.

\section{Mikroba saluran pencernaan}

Mikroba saluran pencernaan (bakteri Choliform, $E$. coli, dan total bakteri) pada ayam penelitian tersaji pada Tabel 2. Pemberian probiotik, yaitu pada ayam Grup $\mathrm{B}, \mathrm{C}$, dan $\mathrm{D}$, secara signifikan $(\mathrm{P}<0,05)$ menurunkan kandungan bakteri Choliform dalam ekskreta ayam, yaitu: 18,06\%; 17,09\%; dan 20,97\% lebih rendah daripada kontrol (A). Demikian juga halnya dengan jumlah bakteri $E$. coli pada ayam perlakuan B, C, dan $\mathrm{D}$, mengalami penurunan yang signifikan $(\mathrm{P}<\mathrm{O}, 05)$, masing-masing: $23,94 \%$; 29,87\%; dan 30,93\% lebih rendah daripada kontrol. Total jumlah bakteri/ TPC pada saluran pencernaan ayam perlakuan B, C, dan $\mathrm{D}$, menunjukkan berbeda tidak nyata $(\mathrm{P}>0,05)$ dibandingkan dengan kontrol (A).

Probiotik dapat menjaga keseimbangan mikroba dalam saluran pencernaan, yaitu melalui mekanisme competitive exclution, yaitu kompetisi antara bakteri patogen dengan mikroorganisme probiotik, sehingga bakteri patogen tidak dapat hidup dalam saluran pencernaan dan akan keluar bersama ekskreta (Zurmiati et al., 2014). Keseimbangan mikroba dalam saluran pencernaan terjadi apabila komposisinya terdiri atas $85 \%$ mikroba yang menuntungkan dan $15 \%$ mikroba patogen (Sjofjan, 2003). Pemberian probiotik dapat menciptakan keseimbangan mikroflora usus, karena 
adanya bakteri asam laktat di dalam usus ayam dapat menciptakan suasana asam, sehingga dapat menekan pertumbuhan bakteri patogen di dalam usus halus (Purwati et al., 2005). Hasil penelitian ini didukukung oleh Yamamoto et al. (2004; 2007) bahwa adanya mikroba probiotik pada produk pakan terfermentasi dalam ransum dapat menyebabkan pengurangan bakteri patogen, termasuk Salmonella dan Campylobacter di saluran pencernaan ternak. Hal senada dilaporkan oleh Hasal et al. (2016) bahwa penggunaan produk pakan fermentasi basah dengan mikroba probiotik dapat menyebabkan peningkatan kinerja produksi ayam secara signifikan. Penelitian yang sama dilaporkan oleh Tedesco et al.(1994) bahwa pemberian S. cerevisiae pada ransum dapat menurunkan populasi bakteri pathogen dalam saluran pencernaan kelinci. Probiotik khamir $S$. cerevisiae dapat memacu pertumbuhan kelompok bakteri aerob dan anaerob yang menguntungkan di dalam usus kelinci. Pada pada ayam broiler pemberian pemberian campuran Saccharomyces cerevisiae dengan Streptoccus faecum dapat menekan populasi Eschericia coli sampai 50\% (Kumphrechi et al., 1994). Hasil penelitian ini didukung oleh Phuoc et al. (2017) dan Han et al. (1999), bahwa populasi bakteri Choliform, bakteri $E$. coli dan bakteri aerobik dalam ekskreta usus rata-rata terendah pada kelinci yang ditambah dengan probiotik L. acidophilus dibandingkan dengan mereka yang diberi makan kontrol.

\section{Kadar Ammonia dalam Ekskreta}

Pemberian 0,10-0,30\% probiotik Saccharomyces spp.N-2 secara signifikan $(\mathrm{P}<0,05)$ menurunkan kandungan amonia $\left(\mathrm{N}-\mathrm{NH}_{3}\right)$ dalam ekskreta ayam (Tabel 2). Kandungan amonia dalam ekskreta ayam perlakuan $\mathrm{B}, \mathrm{C}$, dan $\mathrm{D}$, menurun masing-masing: 11,99\%; 12,37\%; dan $15,38 \%$ nyata $(\mathrm{P}<0,05)$ lebih rendah daripada kontrol (A).

Probiotik khamir Saccharomyces spp. sebagai sumber probiotik dalam ransum signifikan dapat menurunkan konsentrasi gas ammonia dalam ekskreta ayam. Penurunan konsentrasi gas ammonia dalam ekskreta ayam tersebut disebabkan karena mikroba probiotik mampu menekan aktivitas enzim urease dan dapat menurunkan jumlah asam urat dalam saluran pencernaan ayam, karena asam urat sudah dimanfaatkan menjadi protein mikrobial (Chiang dan Hsieh, 1995; Yeo dan Kim, 1997). Dilaporkan oleh Nguyen et al. (2019), bahwa suplementasi $0,30 \%$ probiotik dalam ransum babi, itik, dan ayam, signifikan dapat meningkatkan kecernaan nutrisi, menekan bakteri patogen, serta emisi gas berbahaya (Nguyen et al., 2019; Lokman et al., 2015; Carvalho et al., 2019). Hasil penelitian ini didukung oleh Chen et al., (2007); Roni et al., (2014); Puspani et al., (2014). Hal yang sama dilaporkan oleh Bidura et al. (2014), bahwa suplementasi kultur Saccharomyces spp yang diisolasi dari feses sapi bali sebanyak 0,20\% dalam ransum nyata dapat meningkatkan penampilan dan menurunkan kadar gas ammonia ekskreta broiler. Bakteri asam laktat sangat survive dalam saluran pencernaan ternak unggas, dan hal inilah yang dapat menyebabkan jumlah bakteri E.choli dan kadar $\mathrm{N}^{-\mathrm{NH}_{3}}$ dalam ekskreta menurun.

\section{SIMPULAN}

Berdasarkan hasil penelitian ini dapat disimpulkan bahwa suplementasi 0,10-0,30\% probiotik Saccharomyces spp.N-2 (isolat ragi Tape) dalam ransum ayam petelur umur 40-50 minggu dapat meningkatkan kecernaan bahan kering, bahan organik, dan protein kasar pakan. Sebaliknya, menurunkan jumlah bakteri Choliform dan E.coli, serta kandungan gas amonia dalam ekskreta ayam.

\section{UCAPAN TERIMAKASIH}

Penulis mengucapkan banyak terimakasih kepada Rektor dan Ketua Lembaga Penelitian dan Pengabdian kepada Masyarakat (LPPM) Universitas Udayana, atas ijin dan bantuan dana yang diberikan sehingga penelitian sampai penyusunan paper ini dapat terselesaikan. Kepada saudara Andi Udin Saransi, SPt., MPt. atas bantuannya dalam analisis selama di Laboratorium.

\section{DAFTAR PUSTAKA}

Asli, M. M., Hosseini S. A., Lotfollahian H., Shariatmadari F. 2007. Effect of probiotics, yeast, vitamin e and vitamin $C$ supplements on performance and immune response of laying hen during high environmental temperature. Int J Poult Sci. 6:895-900.

Assocciation of Official Analytical Chemists. 2005. Official Methods of Analysis. 15 $5^{\text {th }}$ Edition. Associoation of Analytical Chemists, Arlington, Virginia pp. 1230

Barrow, P. A. 1992. Probiotics of Chickens, in: Probiotics The Scientific Basis. Ed. R. Fuller. First Ed. Chapmann and Hall, London. p.: 225-250.

Bidura, I G. N. G. 2007. Aplikasi Produk Bioteknologi Pakan Ternak. UPT Penerbit Universitas Udayana, Denpasar.

Bidura, I G. N. G. 2019. Supplementation of probiotics Saccharomyces spp.Kb-13 in diets on egg productions, egg characteristics, and yolk cholesterol in egg of Lohmann Brown laying hens. Majalah Ilmiah Peternakan Vol. 22 (3): 140-148

Bidura, I G. N. G. 2020. Daun Herbal Dan Probiotik Alternatif Pengganti Antibiotik Growth Promotor 
(Agps) Pada Ternak. Penerbit Swasta Nulus, Jl. Batanghari, Denpasar, Bali

Bidura, I G. N. G., D. P. M. A. Candrawati, dan D. A. Warmadewi. 2010. Pakan Unggas. Konvensional dan Inkonvensional. Penerbit Udayana University Press, Denpasar

Bidura, I G. N. G. and N. W. Siti. 2017. Selection and Implementation of Probiotics Saccharomyces spp. $\mathrm{Kb}-05$ and Saccharomyces spp.Kb-08 Isolated from Buffalo Ruments to Increase the Nutritional Value of Rice Bran. J. Biol. Chem. Research. Vol. 34 (2), 866-877

Bidura, I G. N. G., D. P. M. A. Candrawati, dan D. A. Warmadewi. 2015. Selection of Khamir Saccharomyces spp. Isolated from Colon of Native Chickens as a Probiotics Properties and has CMCase Activity. J. Biol. Chem. Research. Vol. 32, (2), 683-699

Bidura, I G. N. G., D. P. M. A. Candrawati, and I. B. G. Partama. 2014. Selection of Saccharomyces spp isolates (isolation from colon beef of Bali cattle) as probiotics agent and colon cancer prevention and its effect on pollard quality as feed. Journal of Biological and Chemical Research Vol. 31 (2), 1043-1047

Bidura, I G. N. G., N. W. Siti, and I. B. G. Partama. 2019. Effect of probiotics, Saccharomyces spp.Kb-5 and $\mathrm{Kb}-8$, in diets on growth performance and cholesterol levels in ducks. South African Journal of Animal Science Vol. 49 (No. 2): 219-226. http:// dx.doi.org/10.4314/sajas.v49i2.2

Bidura, I G. N. G., Partama, I. B. G., Putra, D. K. H. and U. Santoso. 2016. Implementation on diet of probiotic Saccharomyces spp.SB-6 isolated from colon of Bali cattle on egg production and egg cholesterol concentration of Lohmann brown laying hens. Int. J. Curr. Microbiol. App. Sci. Volume 32 (2), 683-699

Bidura, I G. N. G., N. W. Siti, and I. B. G. Partama. 2019. Partama Effect of probiotics, Saccharomyces spp. $\mathrm{Kb}-5$ and $\mathrm{Kb}-8$, in diets on growth performance and cholesterol levels in ducks. South African Journal of Animal Science Vol. 49 (2), 219-226

Bidura, I G. N. G., I. P. Suyadnya, I.G. Mahardika, I. B. G. Partama, I G. L. Oka, and I G. A. I. Aryani. 2012. The implementation of Saccharomyces spp.n-2 isolate culture (isolation from traditional yeast culture) for improving feed quality and performance of male Bali duckling. Agricultural Science Research Journal Vol. 2 (9), 486-492

Bidura, I G. N. G., dan G. S. Gomes. 2019. Manajemen Nutrisi Ternak Babi. Kebutuhan dan Defisiensi Zat Makanan. Penerbit Swasta Nulus, Denpasar, Bali

Carvalho, M. D. C. D., I G. N. G. Bidura, I. B. G. Partama, and N.W. Siti. 2019. Effect of drinking water supplementation with extract fermented Tamarindus indica by Saccharomyces spp on egg production, feed digestibility and $\mathrm{N}-\mathrm{NH}_{3}$ content in excreta laying hens. World Journal of Pharmaceitical and Life Sciences Vol. 5 (10): 01-06 Chen, C. Y., Chen, S. W. and H. T. Wang. 2017. Effect of supplementation of yeast with bacteriocin and Lactobacillus culture on growth performance, cecal fermentation, microbiota composition, and blood characteristics in broiler chickens. Asian-Australas J Anim Sci Vol. 30 (2), 211-220

Chiang, S. H., and W. M. Hsieh. 1995. Effect of direct feed microorganisms on broiler growth performance and litter ammonia level. AJAS 8: 159-162

Ezema, C. and D. C. Eze. 2015. Probiotic Effect of Yeast (Saccharomyces cerevisiae) on Hen-Day Egg Performance, Serum and Egg Cholesterol Levels in Laying Chicken. Pakistan Journal of Nutrition 14 (1), 44-46

Fardiaz, S. 1992. Mikrobiologi Pengolahan Pangan Lanjut. Depertemen Pendidikan dan Kebudayaan Direktorat Jenderal Pendidikan Tinggi Pusar Antar Universitas Pangan dan Gizi. Institut Pertanian Bogor. Bogor.

Hasanuddin, A., Rusdi and Rosmiaty Arief. 2017. Effects of inclusion of fermented carrageenan by-products in the basal diet of broiler chickens on growth performance, blood profiles and meat composition. Int. J. Poult. Sci., 16 (5): 209-214)

Hasan, S.A.J., Lokman, I.H., Naji, S.A., Zuki, A.B.Z. and A.B. Kassim, 2016. Effects of dietary supplementation of wet fermented feed with probiotic on the production performance of Akar Putra chicken. Asian J. Poult. Sci. 10, 72-77

Kumprechi, I., P. Zobac, Z. Gasnarek dan E. Robosova. 1994. The effect of continues applications of probiotics preparations based on $S$. cerevisiae var elipsoideus and Strptococcus faecum C- 68(SF-68) on chicken broiler yield. Zivoscisma-yroba 39(6): 491-503.

Lokman, I.. H., Jawad, S.H., Zuki, A. B. Z. and A. B. Kassim. 2015. Effect of dry probiotic supplemented fermented feed on production performance of akar putra chicken. Int. J. Poult. Sci.14, 420-426.

Nguyen, D. H., C. M. Nyachoti and I. H. Kim. 2019. Evaluation of effect of probiotics mixture supplementation on growth performance, nutrient digestibility, faecal bacterial enumeration, and noxious gas emission in weaning pigs. Italian Journal of Animal Science, 18:1, 466-473, DOI: 10.1080/1828051X.2018.1537726

Partama, I. B. G. and I G. N. G. Bidura. 2019. Provision of Saccharomyces cereviseae probiotics in rice bran-based rations on the performance of balinese 
duckling (Anas sp). J. Biol. Chem. Research. Vol. 36, No. 1, Part C: 35-39

Phuoc, T.L. and U. Jamikorn. 2017. Effects of probiotic supplement (Bacillus subtilis and Lactobacillus acidophilus) on feed efficiency, growth performance, and microbial population of weaning rabbits. AsianAustralas J Anim Sci 30, 198-205

Purwati, E., S. Syukur, dan Z. Hidayat. 2005. Lactobacillus, Isolasi dari Biovicophitomega sebagai probiotik. Lembaga Ilmu Pengetahuan Indonesia, Jakarta.

Puspani, E., D. P. M. A. Candrawati, and I G. N. G. Bidura. 2016. Implementation of probiotics cellulolitic B-7 bacteria (isolation from buffalo rumen) into ration on the performance, abdominal fat and serum cholesterol of duck. Int. J. Curr. Microbiol. App. Sci. Vol. 5 (11), 432-441

Roni, N. G. K., E. Puspani, and I G. N. G. Bidura. 2014. Probiotics feeding managementas an effort for pressuring body fat and excrete ammonia concentration of bali drake. Majalah Ilmiah Peternakan 18 (3): 119-124

Saransi, A. U., T. I. Putri, I M. Mudita, D. P. M. A. Candrawati, dan I G. N. G. Bidura. 2010. Buku Penuntun Praktikum. Laboratorium Nutrisi, Fakultas Peternakan, Universitas Udayana, Denpasar

Scott, M. L., M. C. Neisheim, M.C. and R. J. Young. 1982. Nutrition of The Chickens. 2nd Ed. Publishing by : M. L. Scott and Assoc. Ithaca, New York.

Siti, N. W., D. P. M. A. Candrawati, D. A. Warmadewi, and I G. N. G. Bidura. 2014. Isolation of Saccharomyces $s p p$ from Manure of Beef Bali cattle as a probiotics properties and has CMC-ase activity to improve nutrient quality of rice bran. Journal of Biological and Chemical Research Vol. 31 (1), 39-52

Sjofjan, O. 2003. Kajian probiotik (Aspergillus niger dan Bacillus spp) sebagai imbuhan ransum dan implikasi efeknya terhadap mikroflora usus serta penampilan produksi ayam Petelur. Disertasi. Universitas Padjajaran, Bandung.

Steel, R.G.D. and J. H. Torrie. 1989. Principle and Procedure of Statistics. Mc Graw Hill Book Co. Inc., New York.

Syafitri, Y. E., V. D. Yunianto, dan N. Suthama. 2015. Pemberian ekstrak daun beluntas (Pluchea indica Less) dan klorin terhadap massa kalsium dan massa protein daging ayam broiler. Anim. Agri. J. 4 (1): 155-164.

Tedesco, D., C Castrovilli, G. Coni, D. Bartoli, V. Vollrto dan F. Polidori. 1994. Use ofprobiotics in the feedingof meat rabbits: Effects on performance and intestinal microorganism. Rivistadj. Coniglicoltura 31 (10): 41-46.

Yamamoto, M., F. Saleh and K. Hayashi. 2004. A fermentation method to dry and convert Shochu distillery by-product to asource of protein and enzymes. J. Poult. Sci., 41: 275-280.

Yamamoto, M., F. Saleh, M. Tahir, A. Ohtuska and K. Hayashi, 2007. The effect of Koji-feed (fermented distillery by-product) onthe growth performance and nutrient metabolizability inbroiler. J. Poult. Sci. 44: 291-296.

Yeo, J. and K.I. Kim. 1997. Effect of feeding diets containing anantibiotic, a probiotic, or yucca extract on growth andintestinal urease activity in broiler chicks. Poult. Sci. 76: 381-385.

Zhen, Y.G., W. Zhao, X. Chen, L.J. Li, H.G. Lee, X.F. Zhang and T. Wang. 2019. Effects of yeast culture on broiler growth performance, nutrient digestibility and caecal microbiota. S. Afr. J. Anim. Sci. vol. 49 (1): 99-108

Zurmiati, M. E. Mahata, M. H. Abbas, Wizna. 2014. Aplikasi Probiotik Untuk Ternak Itik. Jurnal Peternakan Indonesia Vol. 16 (2): 134-144 